\title{
Photosynthetic response of Amphibolis antarctica and Posidonia australis to temperature and desiccation using chlorophyll fluorescence
}

\author{
S. Seddon ${ }^{1,2, *}$ A. C. Cheshire ${ }^{2}$ \\ ${ }^{1}$ Department of Environmental Biology, University of Adelaide, Adelaide, Australia 5005 \\ ${ }^{2}$ South Australian Research and Development Institute (SARDI) (Aquatic Sciences), PO Box 120, Henley Beach, Adelaide, \\ Australia 5022
}

\begin{abstract}
Exposure to desiccation during heat wave conditions $\left(\geq 35^{\circ} \mathrm{C}\right)$ is considered the most likely cause of a sudden dieback of 12700 ha of intertidal and shallow subtidal seagrasses along $95 \mathrm{~km}$ of coast in Spencer Gulf, South Australia. To investigate this hypothesis experiments in a constant environment (CE) room were designed to test the tolerances of 2 shallow subtidal species, Amphibolis antarctica and Posidonia australis, to desiccation for a range of temperatures and exposure times. The first experiment compared the effects of increasing exposure time $(15,30,45,60,80$ and $100 \mathrm{~min}$ ) on photosynthetic efficiency at a relatively mild summer temperature (CE room set to $24^{\circ} \mathrm{C}$ ). The second experiment compared the effects of increasing temperature (CE room temperature set to $18,24,28$ or $\left.32^{\circ} \mathrm{C}\right)$ and exposure time $(0,20$ and $60 \mathrm{~min})$. Photosynthetic efficiency, damage and extent of recovery were determined by chlorophyll fluorescence measured using a pulse amplitude modulated fluorometer. The ability of both species to recover from desiccation decreased at higher temperatures and longer exposure time, with $P$. australis more susceptible to desiccation than A. antarctica. The results indicate that higher temperatures alone did not significantly affect photosynthetic efficiency for either species. Four main responses for maximal quantum yield over a time series were apparent: (1) no difference from controls, (2) a significant degree of photosystem II inhibition followed by complete or (3) partial recovery, and (4) complete inhibition of photosystem II with no recovery. Short exposures to desiccation at lower temperatures generally resulted in moderate stress followed by complete recovery, while at higher temperatures there was only partial recovery, particularly for $P$. australis. However, both species exposed for $1 \mathrm{~h}$ at the highest temperature showed no signs of photosynthetic recovery up to $18 \mathrm{~h}$ after re-immersion, suggesting that significant seagrass dieback is plausible under these conditions in situ, particularly if the seagrasses were exposed to repeated desiccation on consecutive days.
\end{abstract}

KEY WORDS: Seagrass dieback · Pulse amplitude modulated fluorometer $\cdot$ Chlorophyll fluorescence · Inhibition · Recovery

Resale or republication not permitted without written consent of the publisher

\section{INTRODUCTION}

Shallow seagrasses are exposed to a variety of environmental extremes, including high solar radiation, wide temperature fluctuations and exposure to desiccation, all of which are influenced by the prevailing

*E-mail: seddon.stephanie@saugov.sa.gov.au

Present address: SARDI tidal conditions. Though many seagrasses have evolved anatomical and physiological mechanisms to deal with such environmental fluctuations (PérezLloréns \& Niell 1993, Abal et al. 1994, Dawson \& Dennison 1996), rare events can produce conditions beyond the range of physiological tolerance. The effects of temperature extremes have been widely investigated in terrestrial plants (Berry \& Björkman 1980, Berry \& Raison 1981) and marine macrophytes 
(Bulthuis 1987, Davison 1991), but the effects of desiccation on marine plants and seagrasses in particularlar have received less attention.

Photosynthesis is a fundamental process common to all ecosystems, and both temperature and desiccation have been shown to significantly influence this process. The response of seagrasses and other plants to elevated temperatures is not a linear relation. Generally there is a specific optimal temperature for photosynthesis, which is higher than that for optimal growth. When this temperature is exceeded, there is a rapid decline of photosynthesis (Biebl \& McRoy 1971, Bulthuis 1983). Critical thermal stress in Australian seagrasses has been shown to occur at temperatures exceeding $35^{\circ} \mathrm{C}$ (Bulthuis 1983, Ralph 1998). A similar response has been reported for desiccation where net positive photosynthesis is maintained for a defined initial period, beyond which continued desiccation results in negative net photosynthesis and/or permanent cell damage (Beer \& Eshel 1983, Matta \& Chapman 1995).

Heat-induced tissue damage to seagrasses is indicated by brownish-black discolouration of the cell wall and contents (Biebl \& McRoy 1971, Walker \& Cambridge 1995) and the cessation of protoplasmic streaming (Biebl \& McRoy 1971). At the molecular level these effects manifest as changes in the enzyme catalysed reactions of photosynthesis and other processes, such as the active transport of $\mathrm{CO}_{2}$ and $\mathrm{HCO}_{3}{ }^{-}$across plasma and chloroplast membranes (Davison 1991). For plants in general, damage to photosynthetic tissue may range from a loss of specific enzyme activity and changes in membrane function through to a breakdown in cellular integrity as seen in cases of severe thermal stress (Berry \& Björkman 1980). The extent of damage and speed of recovery are related to the degradation rate of damaged proteins (e.g., D1 protein) and subsequent re-synthesis and replacement by new proteins (Krause 1988, Bruhn \& Gerard 1996).

Desiccation causes cellular dehydration, which increases the concentration of electrolytes within the cell, causing changes to membrane-bound structures including the thylakoid (Wiltens et al. 1978). Since chlorophyll protein complexes are contained within the thylakoid membrane, chlorophyll fluorescence is therefore a sensitive indicator of structural damage to this membrane (Schreiber \& Bilger 1987). However, in the short term, there is evidence that exposure to air may enhance photosynthesis in seagrasses due to decreased resistance to $\mathrm{CO}_{2}$ diffusion (Beer \& Rehnberg 1997). When emersed, intertidal Zostera has been shown to utilise $\mathrm{CO}_{2}$ with assimilation rates equal to or higher than those of submerged plants, providing that the leaf is adequately hydrated (Leuschner et al. 1998).

The experiments presented in this paper relate to a sudden dieback of more than 12700 ha of seagrass in
Spencer Gulf, South Australia (Seddon et al. 2000). Notably, seagrass loss occurred only in intertidal and shallow subtidal areas. The most compelling hypothesis regarding causes of a dieback restricted to shallow seagrasses relates to a combination of high temperatures during a period of prolonged hot weather and increased desiccation due to unusually low spring tides (Seddon et al. 2000).

In early February 1993, 1 to 2 negative tides (depending on location) occurred at midday on consecutive days during heat wave conditions where maximum air temperatures reached 35 to $40^{\circ} \mathrm{C}$ (relative humidity 21 to $53 \%$ ). Negative tides along the eastern side of the gulf happen when the tide falls below the Indian Spring Low Water level due to high barometric pressure and/or easterly winds (Noye 1984, S. Seddon pers. obs.). Data from tide gauges situated at the northern and southern extremes of the dieback indicated that seagrasses growing at Indian Spring Low Water may have been exposed to air for approximately 80 to 115 min on the days mentioned above. While no water temperature data are available from this period, field observations on a calm $40^{\circ} \mathrm{C}$ day in 1996 revealed that shallow water $(50 \mathrm{~cm}$ deep) over areas of seagrass dieback reached $32.7^{\circ} \mathrm{C}$.

On the basis of these historical data, the objective of these experiments was to compare the response of 2 predominantly subtidal species affected in the dieback with the environmental conditions before the event. The specific aims were to assess the photosynthetic performance and ability for short-term recovery of Amphibolis antarctica and Posidonia australis in response to increasing temperature and duration of desiccation.

\section{MATERIALS AND METHODS}

Seagrasses were collected in February 1998 from an area adjacent to dieback in Spencer Gulf, South Australia $\left(33^{\circ} 31.0,137^{\circ} 53.5\right)$. The plants were brought to the South Australian Aquatic Sciences Centre (SAASC) and transplanted into $200 \mathrm{ml}$ plastic containers with coarse quartz sand. Typically a single shoot of $P O-$ sidonia australis Hook. f. or stem of Amphibolis antarctica (Labill.) Sonders \& Aschers. ex Ascherson was transplanted into each container, including a small amount of associated roots and rhizome. In some cases dividing shoots of $P$. australis were transplanted as separating them would damage the base of both shoots. A. antarctica stems were thinned to give a density between 2 and 8 heads per stem (a head contains a cluster of 8 to 12 leaves). These seagrass transplants (collectively referred to as experimental units) were maintained in $500 \mathrm{l}$ fibreglass tanks connected to a 
sand-filtered flow-through seawater system, situated outdoors in full sunlight, for 3 mo before the start of the experiments.

Experimental set-up. All trials from the experiments below used the same equipment set-up in a constant environment (CE) room at SAASC. There were 6 glass aquaria (65 1), which were designated either as 'desiccation aquaria' containing only wet sand ( $7 \mathrm{~cm}$ deep) or as 'seawater aquaria' containing sand, seawater (25 $\mathrm{cm}$ deep) and a submersible pump (100 $\mathrm{l} \mathrm{h}^{-1}$ PJP 100, Project, Cittadella, Italy). The design for Expt 1 required 3 seawater aquaria and 3 desiccation aquaria, whereas Expt 2 required 4 seawater aquaria and 2 desiccation aquaria. Within each aquarium, 8 plastic containers were submerged into the sand creating a cylindrical space for the experimental units to slot into, enabling the quick transfer of experimental units between seawater and desiccation aquaria. As this set-up used closed circulation, all aquaria were drained and replaced with fresh seawater and different experimental units were added the afternoon before each trial. Seawater was collected from the outdoor flow-through system at ambient temperature $\left(\sim 19^{\circ} \mathrm{C}\right)$ and allowed to equilibrate gradually with the $\mathrm{CE}$ room temperature to minimise possible temperature shock to the experimental units.

Light was provided by four 1000 W metal halide lights (M1000IV, Osram Sylvania Products Inc, Manchester, USA) suspended by a frame above the 6 aquaria. These were timed to provide a diurnal light cycle of similar intensity and duration to that measured in an outdoor fibreglass tank during February (Fig. 1). Two metal halides were switched on at 08:00 $\mathrm{h}$ and another 2 at 10:00 h, then the first 2 were switched off at 14:30 $\mathrm{h}$ and the last 2 at 16:30 $\mathrm{h}$. The initial and final hours of light were provided by fluorescent lights only (6.2 $\mu \mathrm{mol}$ photons $\mathrm{m}^{-2} \mathrm{~s}^{-1}$ ), which were on continuously between 06:00 and 18:30 h. The metal halides generated a significant amount of heat, resulting in a diurnal water temperature cycle (Fig. 1) analogous to the in situ cycle recorded for shallow seagrass beds during summer (Seddon 2000). Heat from the metal halides was directed away from aquaria by a fan that circulated air through the gap between aquaria and lights. Another fan circulating air across a tray of ice was required as an additional heat sink when all 4 metal halides were on. Humidity in the CE room was set to $30 \%$, but was increased due to evaporation from aquaria with the metal halides on, resulting in a maximum humidity of 55 to $57 \%$ during the time that seagrasses were exposed to air. Temperature was monitored in 2 seawater aquaria and 2 desiccation aquaria by thermistors connected to a data logger (Squirrel 1200 Series, Grant Instruments Cambridge Ltd., Shepreth, UK) and monitored separately with a mercury thermometer in all 6 aquaria.
Pulse amplitude modulated fluorescence measurements. The photosynthetic performance of the seagrass experimental units under different experimental conditions was determined by chlorophyll fluorescence using a pulse amplitude modulated (PAM) fluorometer (Diving-PAM; Walz, Effeltrich, Germany). Fluorescence parameters $F_{0}$ (initial chlorophyll fluorescence after dark adaptation [reaction centres open]), $F$ (chlorophyll fluorescence of a light adapted plant), $F_{\mathrm{m}}$ (maximal chlorophyll fluorescence after dark adaptation [reaction centres closed]), $F_{\mathrm{m}}^{\prime}$ (maximal chlorophyll fluorescence of a light adapted plant), $F_{\mathrm{v}} / F_{\mathrm{m}}$ (maximal quantum yield, where $F_{\mathrm{v}}=\left(F_{\mathrm{m}}-F_{0}\right)$ is variable fluorescence) and $\Delta F / F_{\mathrm{m}}{ }^{\prime}$ (effective quantum yield $\left.\left[\left(F_{\mathrm{m}}{ }^{\prime}-F\right) / F_{\mathrm{m}}{ }^{\prime}\right]\right)$ were measured for leaves of the same age and at a fixed position on the leaf. For Amphibolis antarctica, this was mid-leaf on the adaxial surface of the 5th oldest leaf, and for Posidonia australis, this was the upper mid portion of the second oldest leaf (usually there were 3 leaves per shoot). In both cases leaves of intermediate age were sampled as there was less variation in chlorophyll fluorescence relative to older
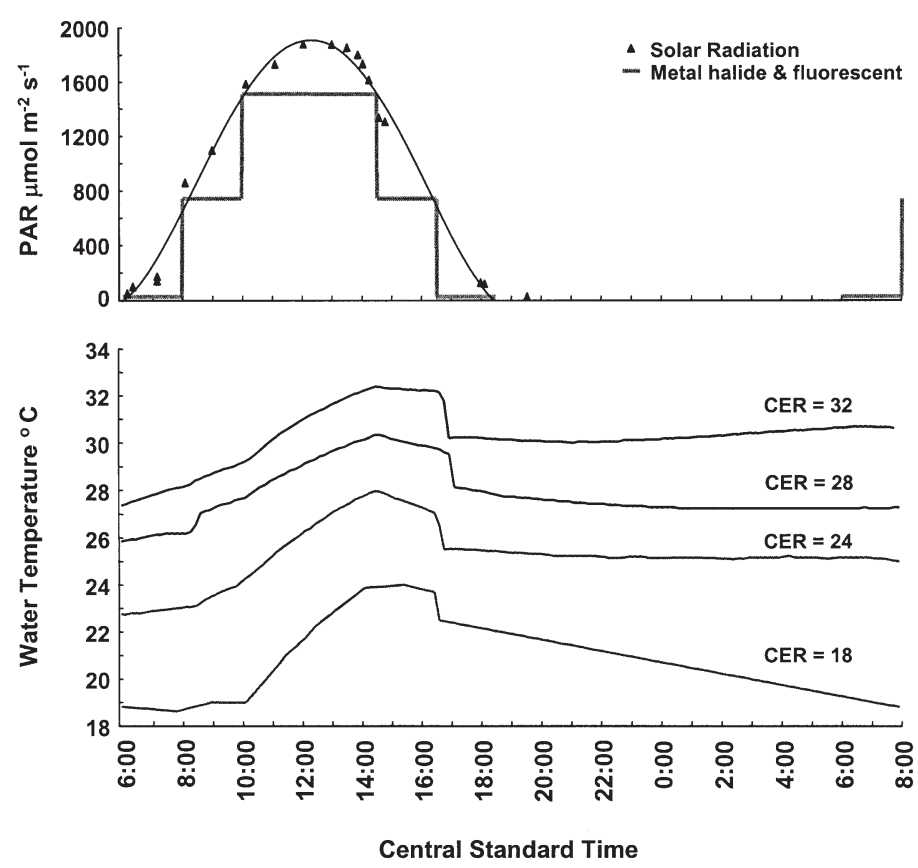

Fig. 1. Experimental light regimen and corresponding diurnal water temperature cycle produced by heat emitted from the metal halide lights for each constant environment room (CER) set temperature. The CER light cycle is compared with solar radiation as measured in an outdoor tank in January 1998 (LiCor quantum sensor $5 \mathrm{~cm}$ underwater). The drop of approximately $1.5^{\circ} \mathrm{C}$ at $16: 30 \mathrm{~h}$ corresponds to the removal and replacement of $5 \mathrm{l}$ of seawater (in all aquaria) to dilute water affected and coloured by pigments leaching from the desiccated seagrasses 
leaves with a lower productivity, or immature leaves with variable chlorophyll content. Dark leaf clips (Diving-LC, Walz) were positioned onto the leaf, with their shutters open, and an initial reading was made for $\Delta F / F_{\mathrm{m}}{ }^{\prime}$. The shutters were then immediately closed and the leaves dark adapted for $15 \mathrm{~min}$, after which a second reading was taken for $F_{\mathrm{v}} / F_{\mathrm{m}}$. Fluorescence measurements on all experimental units for any given sampling period required processing in 2 batches due to a limited number of leaf clips, taking approximately 40 min to complete.

Diving-PAM settings were kept constant throughout the experiments. From preliminary work with these species in natural sunlight, it was found that high irradiance during the middle of the day produced low fluorescence signals due to the 'midday depression' of photosynthetic efficiency as found for seagrasses (Ralph et al. 1998) and algae (Hanelt et al. 1994, Schreiber et al. 1997) elsewhere. High irradiance induced decline of $F_{\mathrm{v}} / F_{\mathrm{m}}$ is known as dynamic photoinhibition, where photosystem II (PSII) downregulation (decline of $F_{\mathrm{v}}$ ) protects against damage to PSII reaction centres from excessive photon flux by thermal dissipation (Huppertz et al. 1990, Henley et al. 1991, Krause \& Weis 1991, Osmond 1994). This problem was solved by increasing the Diving-PAM measuring and saturating light intensities and adjusting the gain accordingly (measuring intensity $=10$, saturating intensity $=12$, saturating width $=0.8 \mathrm{~s}$ and gain $=6$ ). These settings are high for plants at low light intensities (i.e. early morning and late afternoon) but necessary to enable the same settings to be used throughout the day, thereby allowing a comparison of the absolute fluorescence parameters $F_{0}, F_{,} F_{\mathrm{m}}$ and $F_{\mathrm{m}}{ }^{\prime}$.

The amount of dead leaf tissue was visually assessed after the completion of each trial. The proportion of black/brown tissue for each leaf (Posidonia australis) or head (Amphibolis antarctica) was estimated to the nearest quarter, then the total amount of black/brown leaf tissue per experimental unit was calculated as the sum of the proportions of black/brown leaves or heads divided by the total number of leaves or heads per experimental unit.

Expt 1: Comparison of desiccation times. The objective of these trials was to compare the effects of increasing desiccation time on both species for a relatively benign summer temperature (CE room setting $24^{\circ} \mathrm{C}$ ). The results from these trials were used to determine the air exposure times for Expt 2. Experimental units of Amphibolis antarctica for the first trial and Posidonia australis for the second were removed from seawater aquaria at 12:00 $\mathrm{h}$ and transferred to desiccation aquaria for $15,30,45,60,80$ or $100 \mathrm{~min}$, then immediately returned to the original seawater aquaria $\left(\mathrm{n}=4\right.$ species $^{-1}$ treatment $\left.^{-1}\right)$. The 6 desiccation treat- ments were interspersed across the 3 seawater aquaria, with replicates randomly ordered within each aquarium (i.e. 2 replicates aquarium ${ }^{-1}$ treatment $^{-1}$ ). Fluorescence was measured before air exposure (between 9:00 and 10:00 h), immediately after the indicated air exposure time (12:30 to 14:30 h) and $2 \mathrm{~h}$ after re-immersion (14:30 to $16: 30 \mathrm{~h})$.

Expt 2: Comparison of desiccation time with temperature. The objective of these trials was to determine the effects of a short and long period of desiccation with increasing temperature on both species of seagrass. Four temperature treatments were compared where the $\mathrm{CE}$ room was set to $18,24,28$ or $32^{\circ} \mathrm{C}$, although because of the diurnal light cycle the temperature was not constant and rose by up to $5^{\circ} \mathrm{C}$ higher than the set temperature (Fig. 1). From the results of Expt 1, it was decided that 20 min air exposure would produce sub-lethal desiccation effects and a high likelihood of photosynthetic recovery for the range of temperatures tested, and that $60 \mathrm{~min}$ air exposure would cause possible lethal effects and a low likelihood of photosynthetic recovery. There were 3 air exposure treatments: 0, 20 and $60 \mathrm{~min}$, where both species were compared simultaneously for each temperature trial. Two seawater aquaria contained plants for the desiccation treatments and 2 contained the controls, with 2 replicates species ${ }^{-1}$ aquarium $^{-1}$ (i.e. a total of 4 experimental units species ${ }^{-1}$ treatment $^{-1}$ ). While it was possible to intersperse control and air exposed plants across the 4 seawater aquaria, it was important to keep them separate particularly during recovery to prevent dying seagrass from affecting control plants (e.g., leaching of pigments and changes in water chemistry). In addition, as there was 1 control treatment, an extra 4 experimental units were required in each control seawater aquarium to balance the number of experimental units within each seawater aquarium to 8. Because of the limited number of experimental units, these additional 'spare' plants were neither replaced nor measured throughout the 4 temperature trials.

Fluorescence was measured for all experimental units at low light early in the morning (between 07:00 and 08:00 h) to obtain $F_{\mathrm{v}} / F_{\mathrm{m}}$. At 12:00 h the experimental units were transferred to desiccation aquaria for the specified time, then returned to the original seawater aquaria, where fluorescence was measured at 0,1 and $3 \mathrm{~h}$ after re-immersion. Final measurements were made the following day (between 06:30 and 07:30 h) after $18 \mathrm{~h}$ of re-immersion.

Expt 3: Comparison of desiccation rates with temperature. The objective of these trials was to compare the desiccation rates of Amphibolis antarctica and Posidonia australis. Five A. antarctica heads and 5 P. australis shoots (with fibrous leaf sheaths removed) 
were exposed to air at a given temperature $\left(18,24,28\right.$ or $\left.32^{\circ} \mathrm{C}\right)$ and relative humidity of $55 \%$. Seagrass heads or shoots were removed from seawater, the excess water was shaken off (but not blotted with paper as this would remove the surface film of water) and each head or shoot was weighed after $0,10,20,30,40,60,80,100$ and $120 \mathrm{~min}$ of exposure to air. At the end of each temperature trial all samples were dried for $24 \mathrm{~h}$ at $60^{\circ} \mathrm{C}$ to obtain dry weights. Dehydration rates were calculated as a percentage of the initial fresh weight standardised against dry weight (Pérez-Lloréns et al. 1994).

Data analysis. $F_{\mathrm{v}} / F_{\mathrm{m}}$ data from Expt 2 were compared using 3-factor ANOVA for each sampling time. These data were not analysed as a time series due to statistical dependence between samples through time within a trial. Variance heterogeneity was checked using Cochran's test and data were transformed when required. Post hoc comparison of means for significant main effects or interactions was done using Tukey's test. Because of the bimodal nature of the $F_{\mathrm{v}} / F_{\mathrm{m}}$ data after desiccation, a variation on the arcsine transformation described by Anscombe in 1948 (Zar 1984) was required to improve variance heterogeneity and normality of the data.

\section{RESULTS}

\section{Desiccation times}

A clear difference in response to increased air exposure time was evident between Amphibolis antarctica and Posidonia australis (Fig. 2). There was virtually no change in $F_{\mathrm{v}} / F_{\mathrm{m}}$ for A. antarctica after 15 min air exposure, while $F_{\mathrm{v}} / F_{\mathrm{m}}$ decreased for all other exposure times ${ }^{2}$. Some recovery occurred after $2 \mathrm{~h}$ re-immersion for $A$. antarctica exposed for 30 and $45 \mathrm{~min}$ to air, but there was no indication of recovery after 60,80 and 100 min exposure and $F_{\mathrm{v}} / F_{\mathrm{m}}$ continued to decline. $P$. australis exposed to 15 min desiccation showed a larger depression of $F_{\mathrm{v}} / F_{\mathrm{m}}$ relative to

\section{A. antarctica}

\section{P. australis}

3 hours before desiccation
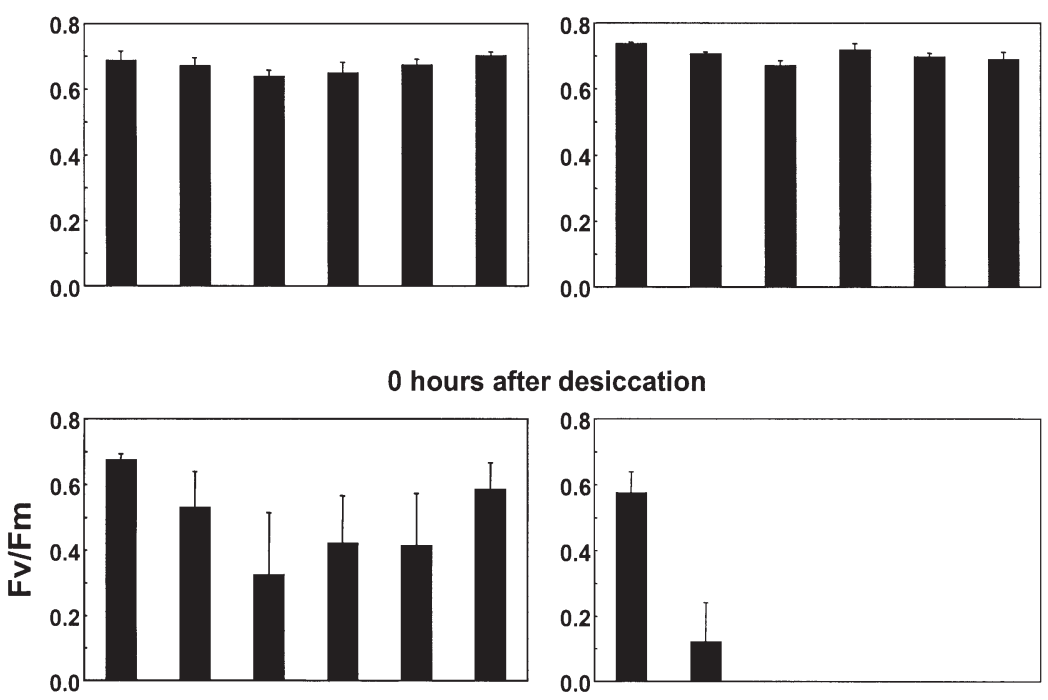

2 hours after desiccation

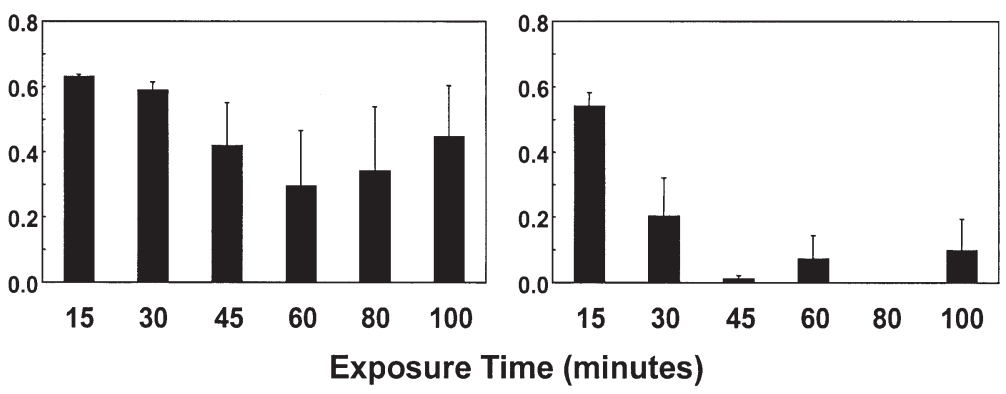

Fig. 2. Comparison of maximal quantum yield $\left(F_{\mathrm{v}} / F_{\mathrm{m}}\right)$ in response to air exposure time for Amphibolis antarctica and Posidonia australis. Symbols represent mean values $\pm \mathrm{SE}(\mathrm{n}=4)$

Table 1. Proportion of black/browning leaf tissue per experimental unit of Amphibolis antarctica and Posidonia australis after the completion of each trial for Expts 1 and 2. All values are expressed as percentages, mean $\pm \mathrm{SE}, \mathrm{n}=5$

\begin{tabular}{|c|c|c|c|c|c|c|}
\hline \multirow[t]{2}{*}{$\begin{array}{l}\text { Expt } 1 \\
\text { Species }\end{array}$} & \multicolumn{6}{|c|}{ Desiccation time (min) } \\
\hline & 15 & 30 & 45 & 60 & 80 & 100 \\
\hline A. antarctica & $41 \pm 15$ & $61 \pm 16$ & $80 \pm 11$ & $100 \pm 0$ & $97 \pm 3$ & $94 \pm 6$ \\
\hline P. australis & $0 \pm 0$ & $88 \pm 13$ & $92 \pm 8$ & $92 \pm 8$ & $100 \pm 0$ & $100 \pm 0$ \\
\hline \multicolumn{7}{|l|}{ Expt 2} \\
\hline \multirow[t]{2}{*}{ Species } & Desiccation & \multicolumn{5}{|c|}{ Constant environment room setting $\left({ }^{\circ} \mathrm{C}\right)$} \\
\hline & time (min) & 18 & & 4 & 28 & 32 \\
\hline \multirow[t]{2}{*}{ A. antarctica } & 20 & $5 \pm 2$ & \multicolumn{2}{|c|}{$11 \pm 5$} & $7 \pm 2$ & $33 \pm 7$ \\
\hline & 60 & $53 \pm 17$ & \multicolumn{2}{|c|}{$49 \pm 10$} & $93 \pm 3$ & $91 \pm 8$ \\
\hline \multirow[t]{2}{*}{$P$. australis } & 20 & $49 \pm 15$ & \multicolumn{2}{|c|}{$38 \pm 13$} & $63 \pm 11$ & $49 \pm 13$ \\
\hline & 60 & $49 \pm 10$ & \multicolumn{2}{|c|}{$75 \pm 25$} & $92 \pm 8$ & $95 \pm 4$ \\
\hline
\end{tabular}




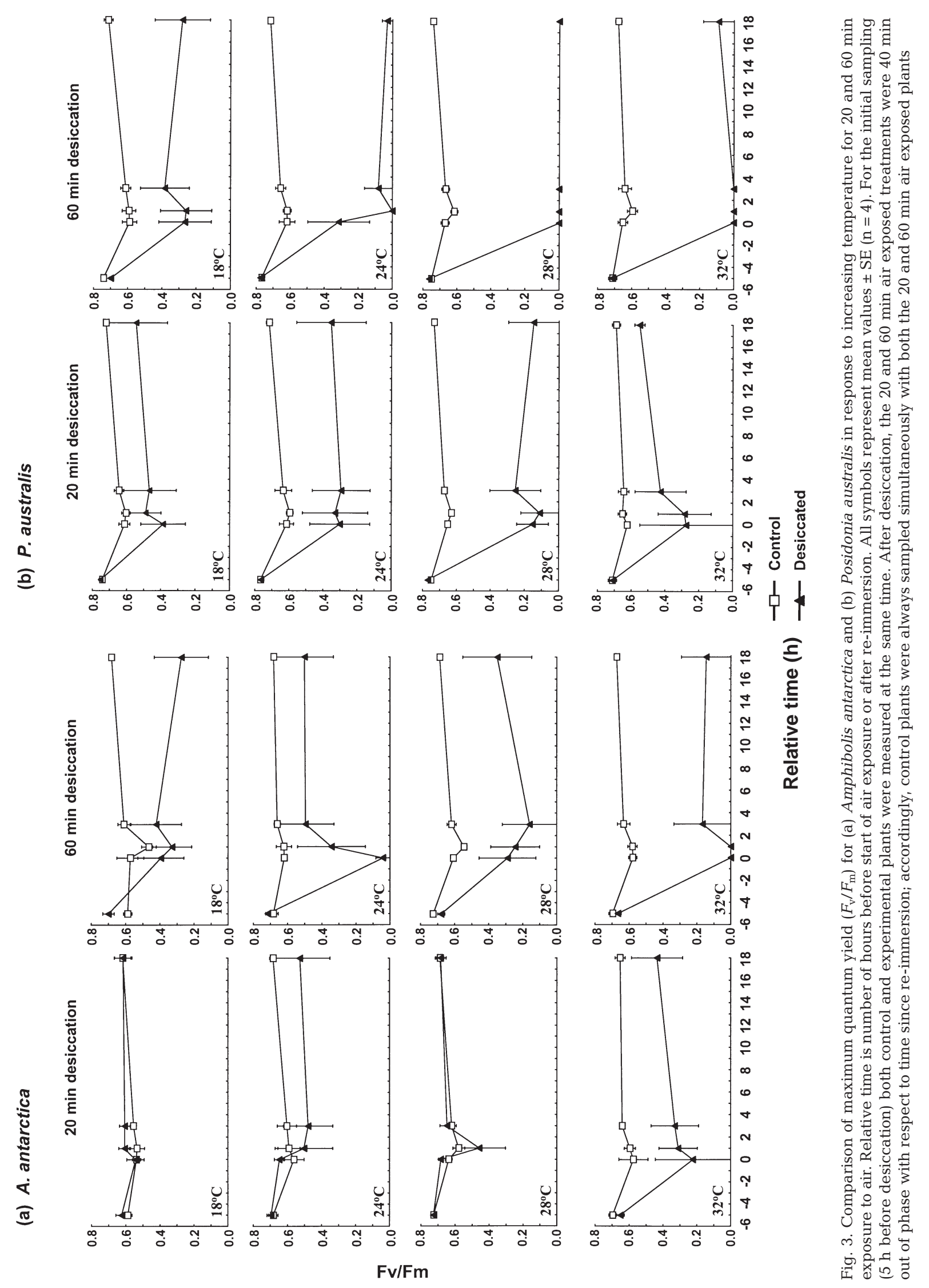


A. antarctica (Fig. 2). However, air exposure times greater than 15 min resulted in the complete inhibition of $F_{\mathrm{v}} / F_{\mathrm{m}}$ for $P$. australis, with little indication of recovery after $2 \mathrm{~h}$ of re-immersion. These results are corroborated by the proportion of necrotic tissue at the end of each trial (Table 1). Here practically all $P$. australis leaf tissue was black/browning after $30 \mathrm{~min}$ in air compared with $60 \mathrm{~min}$ for $A$. antarctica.

\section{Desiccation time versus temperature}

The ability of both species to recover from desiccation decreased at higher temperatures and longer air exposure time (Fig. 3). Recovery of $F_{\mathrm{v}} / F_{\mathrm{m}}$ was generally faster and more complete for Amphibolis antarctica at all temperatures particularly for shorter $20 \mathrm{~min}$ exposures (Fig. 3). In comparison, recovery was less complete for Posidonia australis even for the $20 \mathrm{~min}$ exposures, with no recovery after $60 \mathrm{~min}$ in air except in the short term $\left(0\right.$ to $3 \mathrm{~h}$ ) for the $18^{\circ} \mathrm{C}$ treatment.

Comparison of $F_{\mathrm{v}} / F_{\mathrm{m}}$ results using ANOVA (Table 2) showed significant pre-desiccation variation particularly due to species and temperature. Initial yields during low light in the morning were significantly higher for Posidonia australis (0.74) than Amphibolis antarctica (0.68) and significantly higher at 28 and $24^{\circ} \mathrm{C}$ (Fig. 3). Immediately following re-immersion there was a significant decrease in $F_{\mathrm{v}} / F_{\mathrm{m}}$ with increasing exposure time for both species, with $F_{\mathrm{v}} / F_{\mathrm{m}}$ lower for $A$. antarctica exposed for $60 \mathrm{~min}$ and $P$. australis exposed for 20 and $60 \mathrm{~min}$. After 1 and $3 \mathrm{~h}$ of re-immersion, $F_{\mathrm{v}} / F_{\mathrm{m}}$ remained significantly lower for $A$. antarctica exposed for $60 \mathrm{~min}$ and P. australis exposed for 20 and $60 \mathrm{~min}$. The following morning after $18 \mathrm{~h}$ of re-immersion, $F_{\mathrm{v}} / F_{\mathrm{m}}$ of plants exposed for 20 and $60 \mathrm{~min}$ remained

Table 2. ANOVA summary table of $\mathrm{p}$ values for maximal quantum yield $\left(F_{\mathrm{v}} / F_{\mathrm{m}}\right)$. The data were transformed using for time $-5 \mathrm{~h}$ and a variation on the arcsine transformation by Anscombe (detailed in 'Materials and methods') for times 0 to $18 .{ }^{*}$ Data where transformation has failed Cochran's test for variance homogeneity, accordingly a more conservative alpha value (i.e. $\mathrm{p}=0.01$ ) has been adopted (Underwood 1981). Significant factors and interactions are shown in bold

\begin{tabular}{|lcccccc|}
\hline \multirow{2}{*}{ Source of variation } & \multicolumn{5}{c|}{ Relative time (h) } \\
& -5 & $0^{*}$ & $1^{*}$ & 3 & $18^{*}$ \\
\hline Temperature & $\mathbf{0 . 0 0 0}$ & $\mathbf{0 . 0 0 0}$ & 0.112 & $\mathbf{0 . 0 2 4}$ & $\mathbf{0 . 0 1 1}$ \\
Species & $\mathbf{0 . 0 0 0}$ & 0.418 & 0.533 & 0.160 & 0.605 \\
Desiccation & 0.849 & $\mathbf{0 . 0 0 0}$ & $\mathbf{0 . 0 0 0}$ & $\mathbf{0 . 0 0 0}$ & $\mathbf{0 . 0 0 0}$ \\
Temp $\times$ Species & 0.109 & 0.054 & 0.261 & 0.252 & 0.087 \\
Temp $\times$ Desiccation & 0.282 & 0.594 & 0.054 & 0.190 & 0.882 \\
Species $\times$ Desiccation & 0.335 & $\mathbf{0 . 0 0 1}$ & $\mathbf{0 . 0 0 7}$ & $\mathbf{0 . 0 2 1}$ & $\mathbf{0 . 0 0 2}$ \\
Temp $\times$ Species $\times$ & $\mathbf{0 . 0 0 5}$ & 0.208 & 0.821 & 0.387 & 0.426 \\
Desiccation & & & & & \\
& & & & & & \\
\hline
\end{tabular}

lower than that of the controls; however, $F_{\mathrm{v}} / F_{\mathrm{m}}$ of A. antarctica exposed for 20 min was not significantly lower.

Overall temperature alone appeared to have a minimal effect as there were no significant differences in $F_{\mathrm{v}} / F_{\mathrm{m}}$ for the controls of both species (Fig. 3, Table 2). In addition, the controls from each temperature treatment showed a similar level of PSII downregulation during the period of high irradiance induced dynamic photoinhibition. This can be seen from the measurements made 0 and $2 \mathrm{~h}$ after re-immersion, when the seagrasses were exposed to maximal light levels during the simulated diurnal light cycle (Fig. 1), showing that higher temperatures did not act synergistically with high irradiances to further reduce photosynthetic efficiency (i.e. non-significant temperature $\times$ desiccation interaction, Table 2).

Four general patterns were identified, which summarise the range of responses of $F_{\mathrm{v}} / F_{\mathrm{m}}$ to temperature and desiccation. Response 1 was usually shown by the controls (and Amphibolis antarctica exposed for $20 \mathrm{~min}$ at $18^{\circ} \mathrm{C}$ ) where $F_{\mathrm{v}} / F_{\mathrm{m}}$ essentially remained the same, apart from the usual midday high irradiance downregulation of PSII. Response 2 occurred when PSII downregulation exceeded the typical midday depression (exhibited by the control plants), indicating a shortterm desiccation effect followed by a complete recovery. This is best illustrated by $A$. antarctica exposed for $20 \mathrm{~min}$ at $28^{\circ} \mathrm{C}$ and by Posidonia australis exposed for $20 \mathrm{~min}$ at $18^{\circ} \mathrm{C}$ (although for $P$. australis recovery was not quite complete). The most common effect was response 3, where air exposure caused inhibition of $F_{\mathrm{v}} / F_{\mathrm{m}}$ to exceed the usual midday depression followed by a partial recovery of $F_{\mathrm{v}} / F_{\mathrm{m}}$, indicating more persistent PSII damage that was not repaired after $18 \mathrm{~h}$ of reimmersion (e.g., A. antarctica exposed for $60 \mathrm{~min}$ at all temperatures and $P$. australis exposed for $20 \mathrm{~min}$ at 24 and $32^{\circ} \mathrm{C}$ ). Finally, response 4 response occurred where there was complete inhibition of PSII with no recovery of $F_{\mathrm{v}} / F_{\mathrm{m}}$ upon re-immersion, indicating chronic PSII damage, as found for $P$. australis exposed for $60 \mathrm{~min}$ at 24,28 and $32^{\circ} \mathrm{C}$.

Fluorescence measurements on desiccated plants within a treatment included a composite of responses not distinguishable from the mean values given in Fig. 3. As plants were not arranged in a particular way when transferred to desiccation aquaria, leaves within shoots or heads were orientated haphazardly with respect to the air, lights and wet sand, resulting in a more realistic patchy dehydration of leaves. For example, observations at the completion of each trial showed that an average of 49 to $75 \%$ of leaf tissue was black/browning in Posidonia australis shoots exposed to $60 \mathrm{~min}$ of desiccation at low temperatures (18 and $24^{\circ} \mathrm{C}$ ) compared with 92 to $95 \%$ at high temperatures 


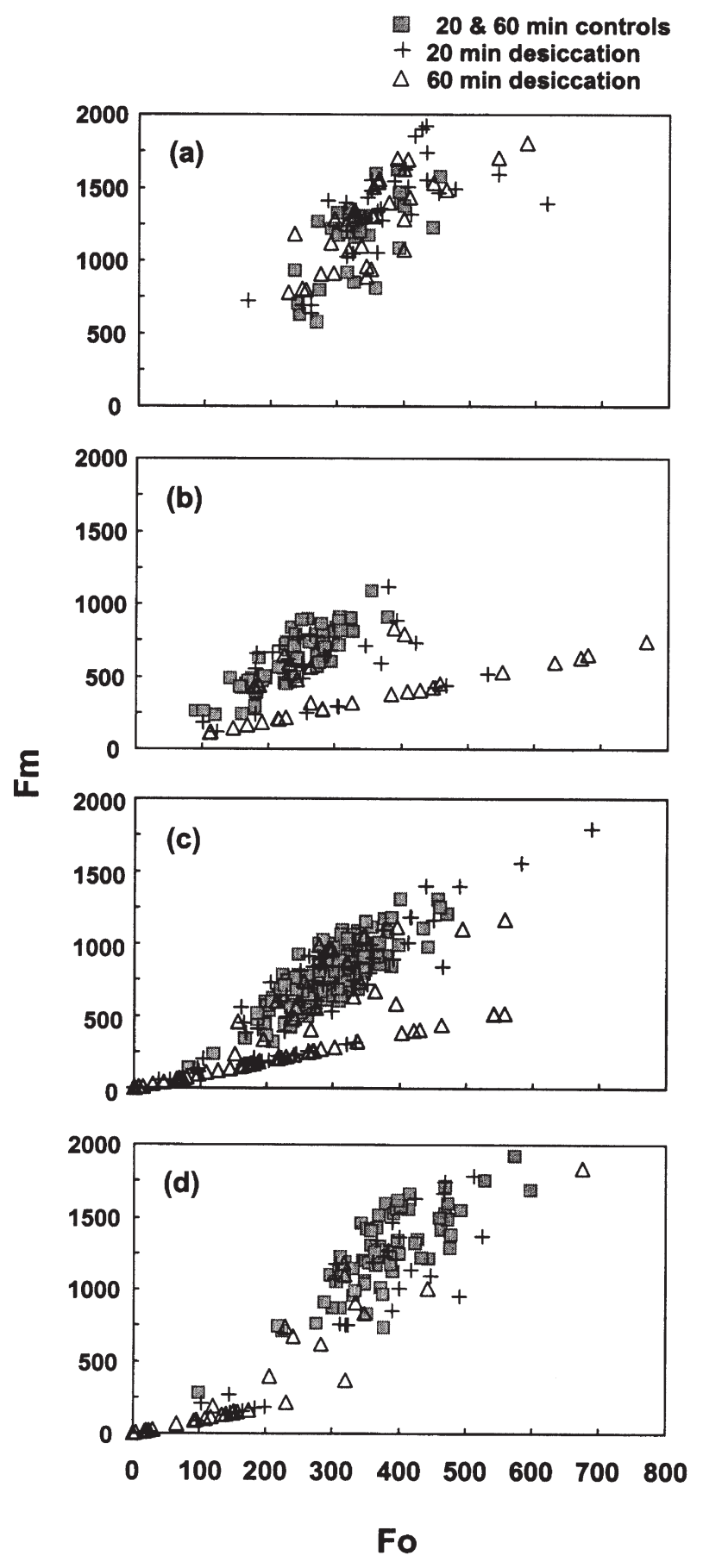

Fig. 4. Collapse of photosynthesis II (PSII) in seagrasses exposed to desiccation. The distribution of parameters $F_{0}$ (initial chlorophyll fluorescence after dark adaptation [reaction centres open]) and $F_{\mathrm{m}}$ (maximal chlorophyll fluorescence after dark adaptation [reaction centres closed] (a) $5 \mathrm{~h}$ before desiccation, followed by the switch from $F_{\mathrm{m}}>F_{0}$ to complete inhibition of PSII where $F_{\mathrm{m}}=F_{0}$ (b) immediately after desiccation, (c) 1 and $3 \mathrm{~h}$ after desiccation, (d) $18 \mathrm{~h}$ after desiccation. Note that with the Diving-PAM (pulse amplitude modulated) fluorometer there is as a low fluorescence signal to noise ratio for readings less than $130 \mathrm{mV}$. For these values the mean error in measurement is estimated as $\pm 12 \mathrm{mV}$ (range 1 to $40 \mathrm{mV}$ ) $\left(28\right.$ and $32^{\circ} \mathrm{C}$ ) (Table 1). Thus, leaves could include relatively unaffected tissue, exhibiting a degree of photoprotective response with $F_{0}$ and/or $F_{\mathrm{m}}$ quenched (Demmig \& Björkman 1987, Franklin et al. 1992), through to severely damaged tissue with $F_{\mathrm{m}}$ and $F_{0}$ chronically inhibited. In the case of the photoprotective response, $F_{\mathrm{m}}$ decreased to a greater or lesser degree until desiccation caused photodamage resulting in the decline of $F_{0}$ and further inhibition of $F_{\mathrm{m}}$ until $F_{\mathrm{m}}=F_{0}$. Here values from desiccated leaves form a distinct line showing no $F_{\mathrm{v}}$ indicating that electron transport has ceased (Fig. 4).

\section{Desiccation rates}

Rates of dehydration were slower for Amphibolis antarctica than for Posidonia australis, particularly at lower temperatures (Fig. 5). At higher temperatures $\left(28\right.$ and $32^{\circ} \mathrm{C}$ ) P. australis was the first to reach $50 \%$ dehydration after 60 min air exposure, with a further $80 \mathrm{~min}$ required at $24^{\circ} \mathrm{C}$ and $100 \mathrm{~min}$ at $18^{\circ} \mathrm{C}$. For $A$. antarctica, $50 \%$ dehydration was not reached until after $75 \mathrm{~min}$ in air at $28^{\circ} \mathrm{C}$ and $32^{\circ} \mathrm{C}$, with a further 100 min required at $24^{\circ} \mathrm{C}$. At $18^{\circ} \mathrm{C}$ A. antarctica was still only $45 \%$ dehydrated after $2 \mathrm{~h}$ of air exposure.

\section{DISCUSSION}

\section{Desiccation times}

The differential response of Amphibolis antarctica and Posidonia australis to desiccation and temperature has significant implications for the distribution and survival of these 2 species in shallow water environments. Despite the relatively mild temperature used for the desiccation time trials, the period that seagrasses were exposed to air was a major determinant of the inhibition of photosynthetic activity. $F_{\mathrm{v}} / F_{\mathrm{m}}$ was completely inhibited for $P$. australis exposed to air for periods greater than $15 \mathrm{~min}$, whereas $A$. antarctica suffered only moderate inhibition (Fig. 2). $F_{\mathrm{v}} / F_{\mathrm{m}}$ for $P$. australis was still chronically inhibited $2 \mathrm{~h}$ after reimmersion, indicating considerable damage to PSII. Even though there was some evidence of recovery for $P$. australis exposed to air for $30 \mathrm{~min}$, it would require several days to monitor the full extent of recovery involving protein resynthesis and repair of damaged photosystems (Bilger et al. 1987, Ralph 1998).

These results provide an estimate of the desiccation time required before significant photosynthetic inhibition indicative of photodamage occurs in Amphibolis antarctica and Posidonia australis. However, the period of exposure required to give rise to chronic inhibi- 
tion in situ is likely to vary considerably. For example, under calm conditions the threshold time for photosynthetic damage may be longer as evaporation from dense seagrass beds is likely to be slower than that from individual shoots. Conversely, strong winds coupled with low humidity are likely to accelerate desiccation relative to that observed under laboratory conditions.

\section{Desiccation time versus temperature}

Higher temperatures combined with prolonged desiccation increased the extent of photosynthetic inhibition and photodamage (Fig. 3). Posidonia australis was more sensitive than Amphibolis antarctica and showed less capacity for recovery, although both species were similarly unable to recover from the combined effects of desiccation and high temperature at $32^{\circ} \mathrm{C}$. This synergistic effect of temperature and desiccation has important consequences for seagrass survival in Spencer Gulf as negative tides generally occur only during the warmer summer months. By comparison, temperature alone had minimal influence on chlorophyll fluorescence of the controls (i.e. no significant difference in $F_{\mathrm{v}} / F_{\mathrm{m}}$ between temperatures for any given sampling period), which supports the view that the temperature range for these experiments did not exceed the critical temperature causing photosynthetic decline for either species. This finding is consistent with the results of Ralph (1998), who demonstrated that electron transport in Halophila ovalis ceased only at temperatures exceeding $37^{\circ} \mathrm{C}$. Not withstanding this result, it is likely that prolonged exposure of seagrasses in water at elevated temperatures may produce detrimental effects. Walker \& Cambridge (1995) showed that chronic heat stress started to cause mortalities of Amphibolis antarctica seedlings after $2 \mathrm{wk}$ at $30^{\circ} \mathrm{C}$, which is well below temperatures capable of producing a rapid decline of photosynthesis.

In contrast to temperature effects, $1 \mathrm{~h}$ of air exposure could produce chronic inhibition of photosynthesis at all temperatures in the short term. For desiccated leaves where $F_{\mathrm{m}}$ approached the same value as $F_{0}$, it is suggested that PSII is inoperable to the point of collapse (Fig. 4). In addition, the existence of a clear gap between the distribution of $F_{0}$ versus $F_{\mathrm{m}}$ and collapse where $F_{\mathrm{m}}=F_{0}$ indicates that desiccation does not produce a continuous decline in photosynthetic capacity, but appears to cause a switch between extreme PSII inhibition to complete PSII collapse where no electron transport is possible (Ralph 1998). Leaves exhibiting PSII collapse were discoloured and had lost their tur-

gor, with absolute values when $F_{\mathrm{m}}=F_{0}$ declining further over time and suggesting chlorophyll degradation (Fig. 4c,d). Subsequent leaching of pigments by desiccated plants into the surrounding seawater also supports this. The switch to PSII collapse occurred only in desiccated leaves and was never found in control plants regardless of the treatment temperature.

Photosynthetic reactions, which have been shown to be sensitive to desiccation, are electron transport between PSII and PSI and water splitting; in desiccation tolerant plants both of these reactions recover quickly when plants are rehydrated (Wiltens et al. 1978). Continued desiccation not only affects these membrane-bound reactions, but also leads to a rapid decline of dark $\mathrm{CO}_{2}$ fixing once a threshold of water loss is reached (Kaiser 1987). The results presented here suggest that 25 to $30 \%$ water loss in Posidonia australis corresponds with chronic inhibition of $F_{\mathrm{v}} / F_{\mathrm{m}}$ whereas for Amphibolis antarctica chronic photosynthetic inhibition occurs at $\sim 40 \%$ water loss (Figs 2, 3 \& 5). While photosynthetic inhibition due to desiccation induced high cellular inorganic ion concentrations is reversible in the short term, more extreme desiccation produces significant cellular shrinkage and volume changes that are non-reversible (Kaiser 1987). It is possible that the switch from chronic inhibition to PSII collapse is indicative of the critical level of cellular dehydration required to produce such non-reversible conformational changes.

The characteristic increase of $F_{0}$, often indicative of photodamage (Krause 1988, Osmond 1994), while occurring in individual leaves in some cases, was not evident in these results as an overall response to desiccation or temperature. It has been shown in algae and terrestrial plants that light, temperature and desicca- 
tion effects strong enough to produce photodamage result in a decrease of $F_{\mathrm{v}} / F_{\mathrm{m}}$. This is primarily due to an increase in $F_{0}$, beyond which any further decrease of $F_{\mathrm{v}} / F_{\mathrm{m}}$ is due to extreme $F_{\mathrm{m}}$ quenching (Demmig \& Björkman 1987, Schreiber \& Bilger 1987, Huppertz et al. 1990). As discussed earlier, the temperatures in these trials were not high enough to inhibit photosynthesis in the controls and cause a concomitant increase in $F_{0}$. However, desiccation definitely caused photodamage sufficient to produce a significant reduction of $F_{0}$ (probably reflecting chlorophyll degradation). Similar dramatic decreases of $F_{0}$ in response to stress have been reported for high light effects on terrestrial plants (Demmig \& Björkman 1987) and extreme heat on seagrasses (Ralph 1998). Analysis of $F_{0}$ quenching by Schreiber \& Bilger (1987) showed an increase in $F_{0}$ for mild desiccation, which reaches a plateau and is maintained over a range of periods of desiccation until a threshold level of water loss is reached, prompting a rapid decline of $F_{0}$. This suggests that if an elevated $F_{0}$ during the early stages of dehydration is to be detected, the duration of desiccation for Amphibolis antarctica and Posidonia australis needs to be shorter than that used in these experiments, or a time series of fluorescence measurements made while seagrasses were exposed to air in the desiccation aquaria.

Only the controls and to a lesser extent Amphibolis antarctica exposed for 20 min showed a full recovery (Response 1) from high light induced PSII downregulation and/or repair of desiccation induced photodamage. Further recuperation may be possible for seagrasses in treatments with incomplete or partial recovery (Responses 2 and 3) where photodamage was not fully repaired by the following morning. However, Adams \& Bate (1994) found that the recovery of Zostera capricorni exposed to desiccation was not due to the rehabilitation of damaged leaves but to the growth of new leaves from basal meristems protected from dehydration by leaf sheaths. For seagrasses showing a type 4 response, no recovery was possible as irreparable damage had occurred where, upon re-immersion, the condition of leaves continued to deteriorate. In this instance dead or dying tissue could still produce a fluorescence signal, but $F_{0}$ and $F_{\mathrm{m}}$ were considerably lower than normal (less than 300, Fig. $4 \mathrm{c}$,d) and $F_{\mathrm{v}} / F_{\mathrm{m}}$ was zero.

\section{Desiccation rates}

Amphibolis antarctica became desiccated more slowly than Posidonia australis, and this was particularly evident at lower temperatures. The dehydration rates presented here were slower than those reported by Pérez-Lloréns et al. (1994), possibly because they used single leaves rather than shoots or heads (leaf clusters), which were used in these experiments to simulate more closely in situ desiccation of seagrass leaves. The slower dehydration rates of A. antarctica relative to $P$. australis seem paradoxical because $A$. antarctica has thinner leaves and observations indicated that it became desiccated more quickly than $P$. australis. Nevertheless, despite becoming visibly dry, A. antarctica re-hydrated more successfully than $P$. australis, which remained limp and discoloured upon re-immersion.

The different rates of desiccation between the 2 species is consistent with the results presented here on the response of photosynthetic efficiency to desiccation with increasing temperature. In addition, these differential desiccation rates agree with the depth distribution for both species where Amphibolis antarctica beds in Spencer Gulf are found in the shallow subtidal areas, between the intertidal zone and subtidal Posidonia meadows. While Posidonia australis is found in the intertidal zone, it has a sporadic distribution with considerably stunted shoots and does not appear to form continuous beds in this zone. In comparison with a true intertidal species, neither seagrass seems entirely suited to the intertidal zone. For example Zostera muelleri not only is desiccated more slowly than $P$. australis and $A$. antarctica, but after reaching $50 \%$ dehydration (in $90 \mathrm{~min}$ ), this species displays significant desiccation resistance with no further water loss over the next 30 min of exposure (Pérez-Lloréns et al. 1994). Interestingly, Björk et al. (1999) found that tropical Halophila ovalis and Halodule wrightii were less physiologically tolerant to desiccation than many of the adjacent subtidal species. They suggest that both these species avoid desiccation by minimising water loss, through a combination of appropriate leaf morphology and orientation, allowing moisture to be retained during low tide.

\section{Conclusions}

Under these experimental conditions, neither species was able to recover completely from $1 \mathrm{~h}$ of desiccation during a period of re-immersion under conditions of low light and darkness. Desiccation therefore appears to constitute a more acute stress for Amphibolis antarctica and Posidonia australis than high temperatures. In the case of the Spencer Gulf seagrass dieback, subtidal seagrasses were exposed to desiccation on consecutive days. Under such conditions it is almost certain that the threshold for photodamage would have been exceeded (i.e. chronic inhibition of $F_{\mathrm{v}} / F_{\mathrm{m}}$, which is not reversible under low light conditions in the late afternoon and early 
evening; Huppertz et al. 1990). It is also probable that this damage would have been compounded with each repeated exposure, producing a pattern of response similar to that shown by algae exposed to successive daily treatments of $50 \%$ desiccation (Hodgson 1981). The loss of photosynthetic capacity and subsequent shedding of necrotic leaves across hectares of seagrass beds (Seddon et al. 2000) would cause a dramatic reduction in the photosynthetically produced $\mathrm{O}_{2}$ available for transport to the roots and rhizomes, leading to anaerobic sediments (Smith et al. 1984). The ensuing mortality of seagrass roots and rhizomes would most likely perpetuate seagrass loss similar to the sulphide induced hypoxia that is thought to have contributed to dieback of Thalassia in Florida Bay (Carlson et al. 1994). Consequently the persistence of shallow seagrass meadows along the eastern coast of Spencer Gulf appears tenuous. An increased frequency and duration of exposure to desiccation (associated with seabed rising; Seddon et al. 2000), combined with the lack of desiccation tolerance of both $A$. antarctica and $P$. australis at high temperatures, are likely to result in ongoing losses to these meadows in the future.

Acknowledgments. This research was supported by a Commonwealth government Australian Postgraduate Industry Award scholarship, with contributions from the South Australian Fishing Industry (Marine Scalefish), SARDI Aquatic Sciences and the South Australian EPA (Marine Environment Protection Fund). Thanks to B. Young and D. Randall for making the CE room go beyond what it was designed for and P. Jennings for helping with the equipment set-up. Climate data were supplied by the Australian Commonwealth Bureau of Meteorology and tidal data by the Ports Corp of South Australia. We also wish to thank 4 anonymous reviewers for comments that greatly improved this manuscript.

\section{LITERATURE CITED}

Abal EG, Loneragan N, Bowen P, Perry CJ, Udy JW, Dennison WC (1994) Physiological and morphological responses of the seagrass Zostera capricorni Aschers. to light intensity. J Exp Mar Biol Ecol 178:113-129

Adams JB, Bate GC (1994) The tolerance to desiccation of the submerged macrophytes Ruppia cirrhosa (Petagna) Grande and Zostera capensis Setchell. J Exp Mar Biol Ecol 183: $53-62$

Beer S, Eshel A (1983) Photosynthesis of Ulva sp. I. Effects of desiccation when exposed to air. J Exp Mar Biol Ecol 70: 91-97

Beer S, Rehnberg J (1997) The acquisition of inorganic carbon by the seagrass Zostera marina. Aquat Bot 56:277-283

Berry J, Björkman O (1980) Photosynthetic response and adaptation to temperature in higher plants. Annu Rev Plant Physiol 31:491-543

Berry JA, Raison JK (1981) Responses of macrophytes to temperature. In: Lang OL, Nobel PS, Osmond CB, Ziegler H (eds) Physiological plant ecology I. Responses to the physical environment. Springer-Verlag, Heidelberg, p 277-338
Biebl R, McRoy CP (1971) Plasmic resistance and rate of respiration and photosynthesis of Zostera marina at different salinities and temperatures. Mar Biol 8:48-56

Bilger W, Schreiber U, Lang OL (1987) Chlorophyll fluorescence as an indicator of heat induced limitation of photosynthesis in Arbutus unedo L. In: Tenhunen JD, Catarino FM, Lange OL, Oechel WC (eds) Plant response to stress. Functional analysis in Mediterranean ecosystems. Springer-Verlag, Berlin, p 391-399

Björk M, Uku J, Weil A, Beer S (1999) Photosynthetic tolerances to desiccation of tropical intertidal seagrass. Mar Ecol Prog Ser 191:121-126

Bruhn J, Gerard VA (1996) Photoinhibition and recovery of the kelp Laminaria saccharina at optimal and superoptimal temperatures. Mar Biol 125:639-648

Bulthuis DA (1983) Effects of temperature on the photosynthesis-irradiance curve of the Australian seagrass, Heterozostera tasmanica. Mar Biol Lett 4:47-57

Bulthuis DA (1987) Effects of temperature on photosynthesis and growth of seagrasses. Aquat Bot 27:27-40

Carlson PR Jr, Yarbro LA, Barber TR (1994) Relationship of sediment sulfide to mortality of Thalassia testudinum in Florida Bay. Bull Mar Sci 53:733-746

Davison IR (1991) Environmental effects on algal photosynthesis: temperature. J Phycol 27:2-8

Dawson SP, Dennison WC (1996) Effects of ultraviolet and photosynthetically active radiation on five seagrass species. Mar Biol 125:629-638

Demmig B, Björkman O (1987) Comparison of the effect of excessive light on chlorophyll fluorescence $(77 \mathrm{~K})$ and photon yield of $\mathrm{O}_{2}$ evolution in leaves of higher plants. Planta 171:171-184

Franklin LA, Levavasseur G, Osmond CB, Henley WJ, Ramus $\mathrm{J}$ (1992) Two components of onset and recovery during photoinhibition of Ulva rotundata. Planta 186:399-408

Hanelt D, Li J, Nultsch W (1994) Tidal dependence of photoinhibition of photosynthesis in marine macrophytes of the South China sea. Bot Acta 107:66-72

Henley WJ, Levavasseur G, Franklin LA, Lindley ST, Ramus J, Osmond CB (1991) Diurnal responses of photosynthesis and fluorescence in Ulva rotundata acclimated to sun and shade in outdoor culture. Mar Ecol Prog Ser 75:19-37

Hodgson LM (1981) Photosynthesis of the red alga Gastroclonium coulteri (Rhodophyta) in response to changes in temperature, light intensity, and desiccation. J Phycol 17: $37-42$

Huppertz K, Hanelt D, Nultsch W (1990) Photoinhibition of photosynthesis in the marine brown alga Fucus serratus studied in field experiments. Mar Ecol Prog Ser 66: 175-182

Kaiser WM (1987) Methods for studying the mechanism of water stress effects on photosynthesis. In: Tenhunen JD, Catarino FM, Lange OL, Oechel WC (eds) Plant response to stress. Functional analysis in Mediterranean ecosystems. Springer-Verlag, Berlin, p 77-93

Krause GH (1988) Photoinhibition of photosynthesis. An evaluation of damaging and protective mechanisms. Physiol Plant 74:566-574

Krause GH, Weis E (1991) Chlorophyll fluorescence and photosynthesis: The basics. Annu Rev Plant Physiol 42:313-349

Leuschner C, Landwehr S, Mehlig U (1998) Limitation of carbon assimilation of intertidal Zostera noltii and Z. marina by desiccation at low tide. Aquat Bot 62:171-176

Matta JL, Chapman DJ (1995) Effects of light, temperature and desiccation on the net emersed productivity of the intertidal macroalga Colpomenia peregrina Sauv. (Hamel). J Exp Mar Biol Ecol 189:13-27 
Noye J (1984) Physical processes and pollution in the waters of Spencer Gulf. Mar Geol 61:197-220

Osmond CB (1994) What is photoinhibition? Some insights from comparisons of shade and sun plants. In: Baker NR, Bowyer JR (eds) Photoinhibition of photosynthesis, from the molecular mechanisms to the field. Bios Scientific, Oxford, p 1-24

Pérez-Lloréns JL, Niell FX (1993) Temperature and emergence effects on the net photosynthesis of two Zostera noltii Hornem. morphotypes. Hydrobiologia 254:53-64

Pérez-Lloréns JL, Strother S, Niell FX (1994) Species differences in short-term pigment levels in four Australian seagrasses in response to desiccation and rehydration. Bot Mar 37:91-95

Ralph PJ (1998) Photosynthetic response of laboratory-cultured Halophila ovalis to thermal stress. Mar Ecol Prog Ser 171:123-130

Ralph PJ, Gademann R, Dennison WC (1998) In situ seagrass photosynthesis measured using a submersible, pulseamplitude modulated fluorometer. Mar Biol 132:367-373

Schreiber U, Bilger W (1987) Rapid assessment of stress effects on plant leaves by chlorophyll fluorescence measurements. In: Tenhunen JD, Catarino FM, Lange OL, Oechel WC (eds) Plant response to stress. Functional analysis in Mediterranean ecosystems. Springer-Verlag, Berlin, p 27-53

Editorial responsibility: Otto Kinne (Editor),

Oldendorf/Luhe, Germany
Schreiber U, Gademann R, Ralph PJ, Larkum AWD (1997) Assessment of photosynthetic performance of Prochloron in Lissoclinum patella in hospite by chlorophyll fluorescence measurements. Plant Cell Physiol 38:945-951

Seddon S (2000) Causes and ecological consequences of the Spencer Gulf seagrass dieback. PhD thesis, University of Adelaide

Seddon S, Connolly RM, Edyvane KS (2000) Large-scale seagrass dieback in northern Spencer Gulf, South Australia. Aquat Bot 66:297-310

Smith RD, Dennison WC, Alberte RS (1984) Role of seagrass photosynthesis in root aerobic processes. Plant Physiol 74: 1055-1058

Underwood AJ (1981) Techniques of analysis of variance in experimental marine biology and ecology. Oceangr Mar Biol Annu Rev 19:513-605

Walker DI, Cambridge ML (1995) An experimental assessment of the temperature responses of two sympatric seagrasses, Amphibolis antarctica and Amphibolis griffithii, in relation to their biogeography. Hydrobiologia 302:63-70

Wiltens J, Schreiber U, Vidaver W (1978) Chlorophyll fluorescence induction: an indicator of photosynthetic activity in marine algae undergoing desiccation. Can J Bot 56: 2787-2794

Zar JH (1984) Biostatistical analysis, 2nd edn. Prentice-Hall, Inc, New Jersey

Submitted: November 30, 2000; Accepted: February 21, 2001 Proofs received from author(s): September 10, 2001 